"Mircea cel Batran" Naval Academy Scientific Bulletin, Volume XIX - 2016 - Issue 1

Published by "Mircea cel Batran" Naval Academy Press, Constanta, Romania // The journal is indexed in:

PROQUEST / DOAJ / DRJI / JOURNAL INDEX / I2OR / SCIENCE LIBRARY INDEX / Google Scholar / Crossref /

Academic Keys / ROAD Open Access / OAJI / Academic Resources / Scientific Indexing Services / SCIPIO

\title{
THE HUMAN FACTOR INFLUENCE ON THE RELATIONSHIP RISK - SAFETY IN THE MARITIME INDUSTRY
}

\author{
Florin NICOLAE ${ }^{1}$ \\ Alexandru COTORCEA ${ }^{2}$ \\ Marian RISTEA ${ }^{3}$ \\ Iulian ROMAN ${ }^{4}$ \\ ${ }^{1}$ Associated Professor, PhD, "Mircea cel Batran" Naval Academy, Constanta, Romania \\ ${ }^{2} \mathrm{PhD}$ attendee, "Mircea cel Batran" Naval Academy, Constanta, Romania \\ ${ }^{3}$ Associated Professor, PhD, "Mircea cel Batran" Naval Academy, Constanta, Romania \\ ${ }^{4} \mathrm{PhD}$ attendee, Technical Academy, Bucharest Romania
}

\begin{abstract}
It is a fact that organizations learn from the failures than successes. Maritime accident investigation reports reveal some information and lessons useful for practice. They may be required to substantiate the source of a set of measures useful for successfully managing and developing a safety management on a realistic basis. In present paper the authors reveal that the accident risk analysis by reliability theory. From this perspective, the authors propose a research and accident investigation methodology which establishes the genesis and the mechanism that caused the accident and the seriousness of the consequences.
\end{abstract}

Key words: human factor, maritime casualties, risk, safety.

\section{Literature review}

The maritime industry is a highly complex economic sector where the human factor is one of the determinant of the system. Although technological progress in the maritime industry has made real contributions to improving safety, the number of naval accidents was maintained at high levels (figure 1).

Determining the causes of naval accidents are one of the most debated topics related to improving maritime safety and investigation reports of these events highlights the human error factor as the main generator of accidentogen chain [1]. This opened concerns increasingly higher among decision makers which manage maritime safety [2-4].

They point out that the complex nature of shipping and specific conditions of seas and oceans, necessary and effective measures are imposed in order to ensure the safety of crew, vessel and cargo and not least the environment [5]. From this point of view, man is key element on board, providing performing of safe voyages. Seamen, regardless of their position on board, is the main determinant of functional relationship cargo-shipcrew environment. In this context, in numerous scientific papers the performance associated with the human element operating in this area is reflected primarily through skills, abilities and demonstrable functional- actionable competences [6]. We must not forget that the human factor performance must be assessed in relation to the working environment conditions. Obsoleted technical conditions of the systems and equipment on board the vessel, improper management, fatigue due to heavy schedules [6] or deficient safety policies [7] are among the main causes of naval incidents. In recent years, to the above are added inadequate crew recruitment policies, in conjunction with the discontent caused by wages. Also, these issues proved to be elements of an inappropriate climate on board, which ultimately affected the safety [8].

The conclusion of experts is that the reduction of accidents will be possible only if the "actors" in the maritime industry will act for identification, classification, evaluation, analysis and management of human error types that lead to accidents. Present paper aims to investigate naval incidents in the period 2011-2014, for determining the contribution of the human factor in the risk safety relationship. The main directions are followed in the research: determining the distribution of naval incidents by vessel type, distribution of incidents on board, determining the factors that have contributed to the incidents and highlight of human error. 
"Mircea cel Batran" Naval Academy Scientific Bulletin, Volume XIX - 2016 - Issue 1

Published by "Mircea cel Batran" Naval Academy Press, Constanta, Romania // The journal is indexed in: PROQUEST / DOAJ / DRJI / JOURNAL INDEX / I2OR / SCIENCE LIBRARY INDEX / Google Scholar / Crossref / Academic Keys I ROAD Open Access / OAJI / Academic Resources / Scientific Indexing Services / SCIPIO

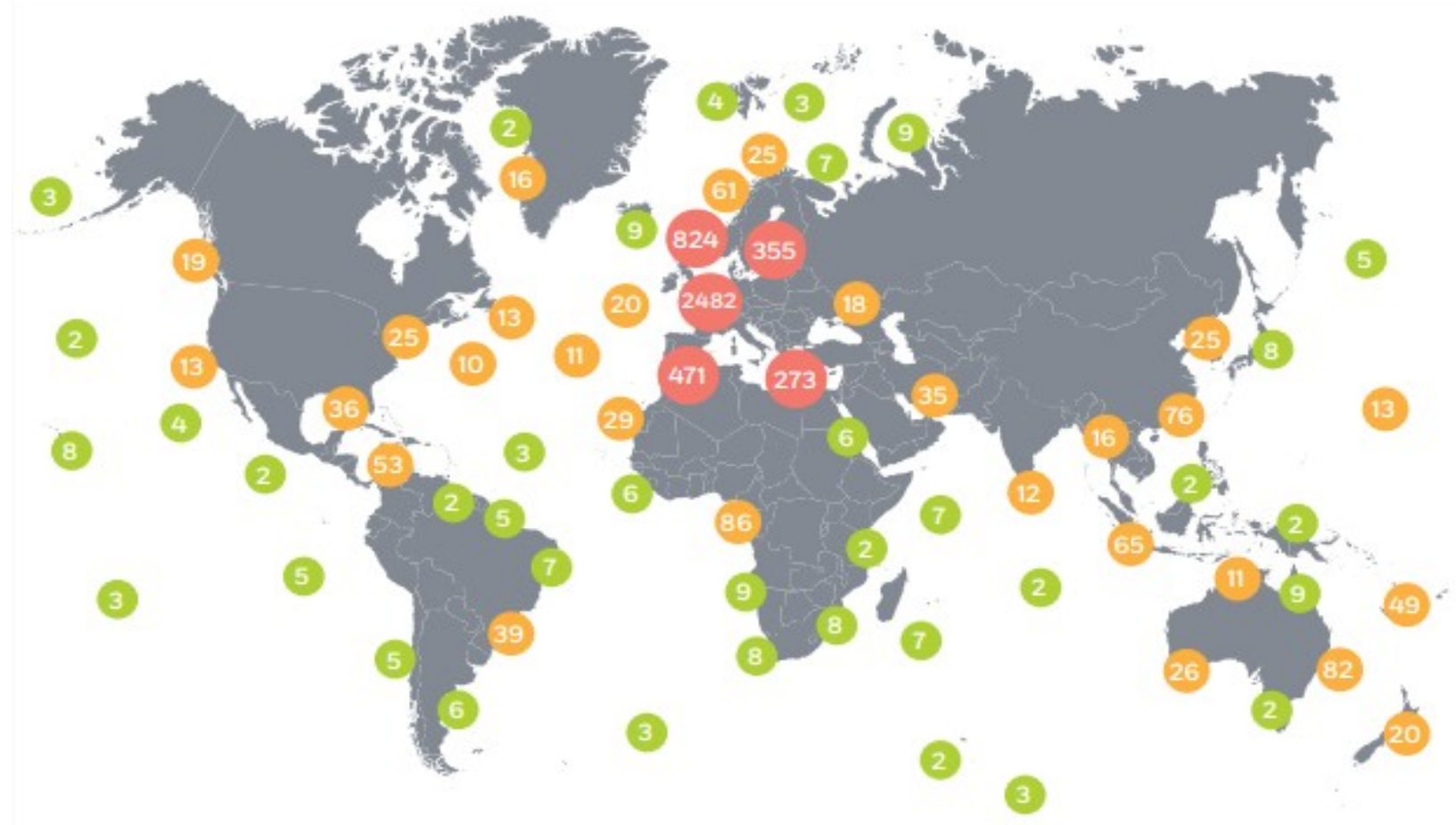

Figure 1 Global distribution of naval accidents

(Source: Annual Overview of Marine Casualties and Incidents 2015)

\section{Naval accidents}

Naval accident is a contingency that involves a ship in the sea or inland waterway. This event can happen at any time when the ship is underway (en route) or stationary, during maintenance in yards or when it is under loading / unloading. Causes of an accident may be of human or technical nature.

Tehnical causes correspond to malfunctions occurred on board (steering system failure, navigation equipment failure, total or partial failure of the propulsion system etc). Human nature causes are associated to improper apply of navigation and protection measures.

In these circumstances, accident investigation is meant to systematically identify the causes and to establish the necessary preventive measures in the future. Given the need to establish the exact causes of the naval accident, International Maritime Organization has standardized investigation methods by adopting the Code for the Investigation of Marine Casualties from 1997. International Convention for the Safety of Life at Sea (SOLAS, 1974) and subsequent regulations, ensures the prevention of accidents and incidents and improve maritime system in order to protect all its components.

The analysis conducted shows that a naval accident can be understood as an event related to the operations carried onboard vessel and may result in: death, loss or serious injury to any person; loss, presumed loss or abandonment of the ship; damage of ship or damage of external maritime infrastructure; endanger the environment due to damage caused to the ship. In the spirit of this approach, a naval incident can be understood as an event or a series of events, other than a maritime accident, which occurred in connection with the operations of a ship. 
"Mircea cel Batran" Naval Academy Scientific Bulletin, Volume XIX - 2016 - Issue 1

Published by "Mircea cel Batran" Naval Academy Press, Constanta, Romania // The journal is indexed in: PROQUEST / DOAJ / DRJI / JOURNAL INDEX / I2OR / SCIENCE LIBRARY INDEX / Google Scholar / Crossref /

Academic Keys / ROAD Open Access / OAJI / Academic Resources / Scientific Indexing Services / SCIPIO

\section{Rsults and discussions}

During research, there have been identified 9180 of naval accidents and incidents that occurred total of 3025 , in $2013-2767$ incidents and between 2011 and 2014. In 2014 there were a accidents, in 2012-2117 and in 2011-1271.

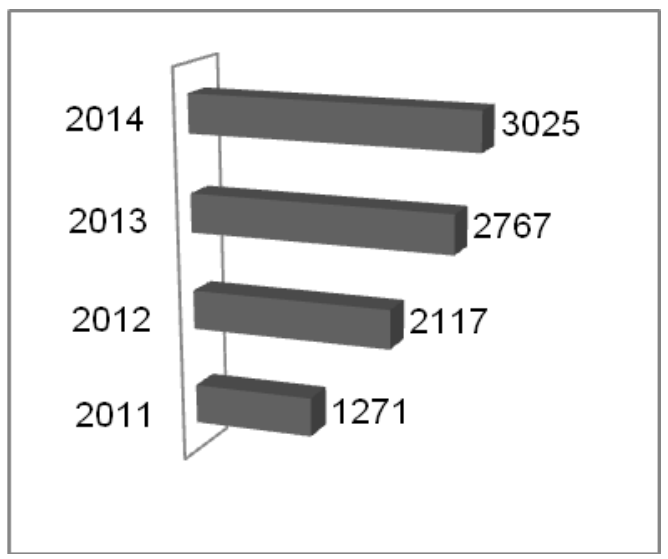

Figure 2. Maritime incidents and accidents reported between 2011 and 2014

Research carried highlights (figure 3) the distribution of accidents and incidents by ship type. For the period $2011-2014,33 \%$ of analyzed accidents is assigned to general cargo, $18 \%$ to container ships, $12 \%$ to bulk carriers, $9 \%$ to oil tankers, $8 \%$ to chemical tankers and $6 \%$ to RO-
RO and ferryboat. An alarming $11 \%$ of all accidents are due to general cargo / bulk carrier, carrying various goods. The list is completed by LNG/ LPG tankers at a rate of $3 \%$.

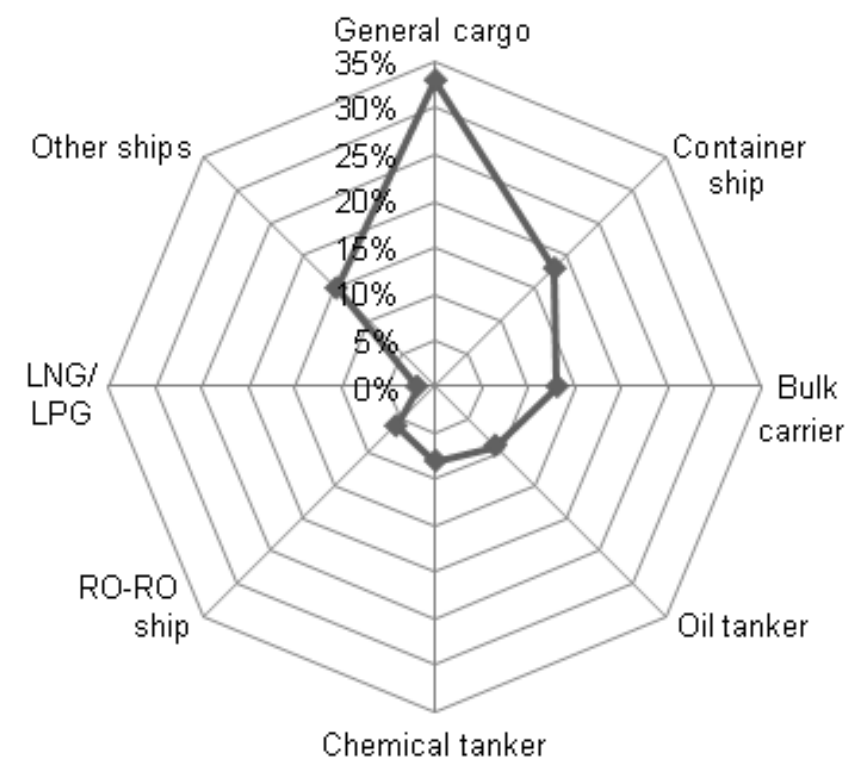

Figure 3. Distribution of marine accidents and incidents by vessel type

Detailed analysis (figure 4) of each event showed that onboard there are several points where accidents occurs with greater frequency. It can be noticed that, for merchant ships, the main location where the frequency of accidents is higher is the machinery space (25\%). This finding does not exclude the other locations like cargo deck area, maneuver area etc. 
"Mircea cel Batran" Naval Academy Scientific Bulletin, Volume XIX - 2016 - Issue 1

Published by "Mircea cel Batran" Naval Academy Press, Constanta, Romania // The journal is indexed in: PROQUEST / DOAJ / DRJI / JOURNAL INDEX / I2OR / SCIENCE LIBRARY INDEX / Google Scholar / Crossref /

Academic Keys / ROAD Open Access / OAJI / Academic Resources / Scientific Indexing Services / SCIPIO

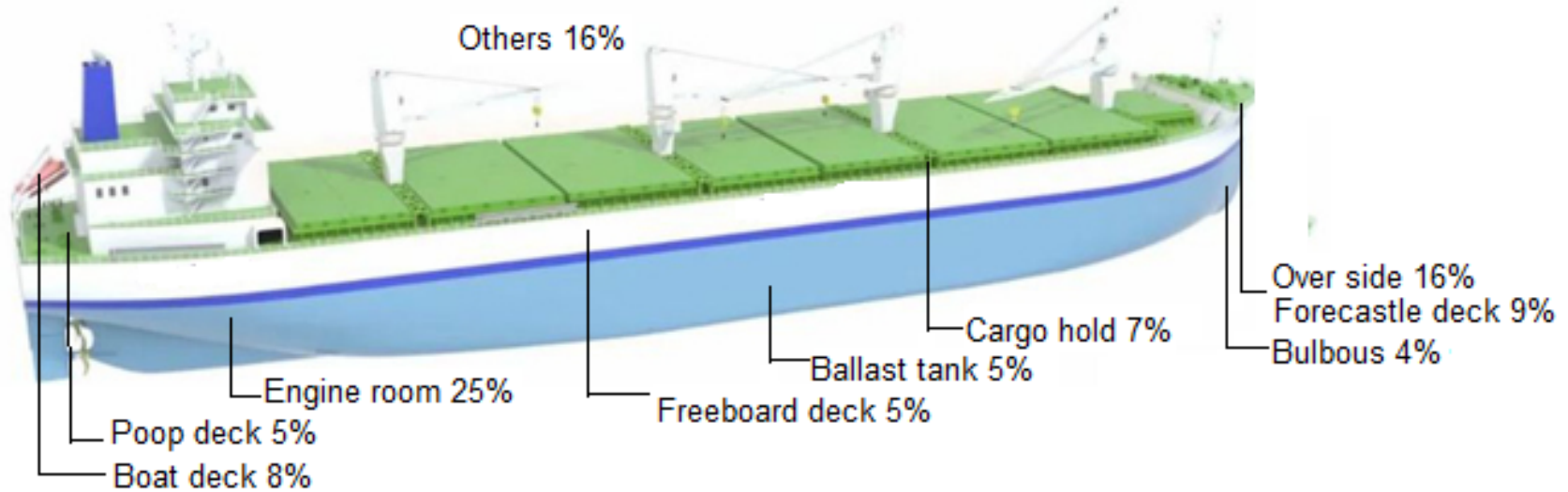

Figure 4. Distribution of accidents and incidents on board

Research also highlights distribution of naval accidents and incidents by causes. Thus, in figure 5 are presented results for general cargo vessels obtained for analized period, 2011 - 2014. Loss of ship control is in first place with $23 \%$, followed by contact with various floating objects (cargo, iceberg; fixed) with 19\%. Accidents involving collision were $18 \%$, grounding/starnding $16 \%$, damaging the vessel or equipment in $12 \%$, explosions or fires $9 \%$, flooding or sinking at the rate of $3 \%$ and capsizing the $1 \%$.

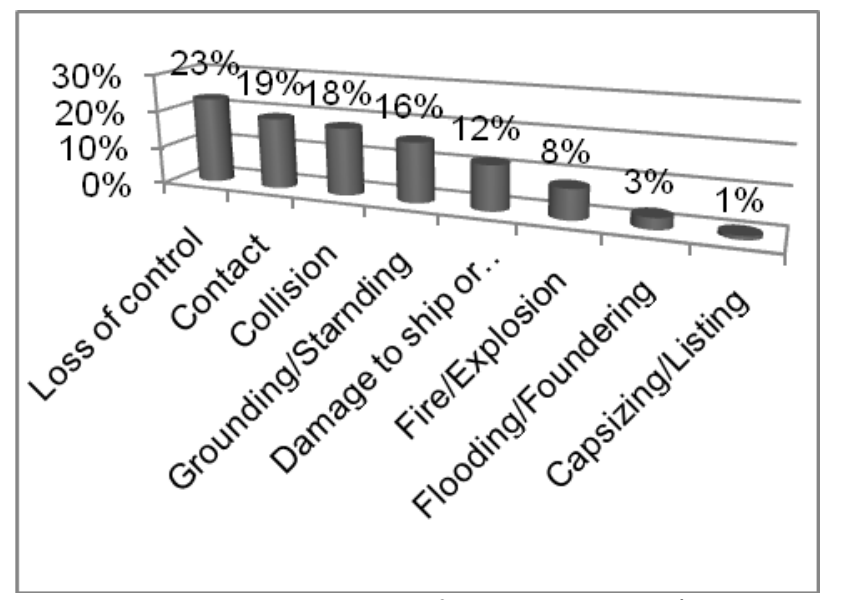

Figure 5 Accidents by causes for cargo ships (2011-2014)

Identifying the main causes of accidents for the period 2011-2014 (figure 6), is another point of conducted research. Of the 912 accidents analyzed, 611 are due to human error, 215 of the accidents are caused by equipment failure, 33 were problems associated with hazardous materials, 23 due to sailing conditions and 29 events are due to various causes.

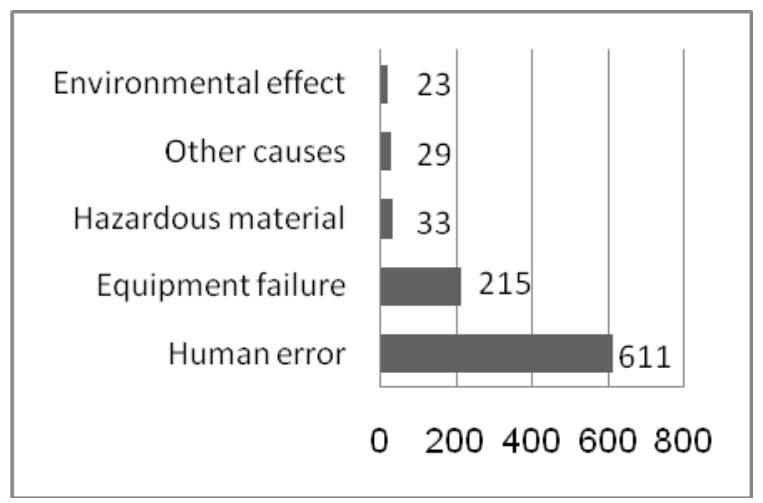

Figure 6. Factors that contributed to naval accidents period 2011-2014 


\begin{abstract}
"Mircea cel Batran" Naval Academy Scientific Bulletin, Volume XIX - 2016 - Issue 1
Published by "Mircea cel Batran" Naval Academy Press, Constanta, Romania /I The journal is indexed in: PROQUEST / DOAJ / DRJI / JOURNAL INDEX / I2OR / SCIENCE LIBRARY INDEX / Google Scholar / Crossref /

Academic Keys / ROAD Open Access / OAJI / Academic Resources / Scientific Indexing Services / SCIPIO
\end{abstract}

\section{Conclusions and future research directions} As noted, the presence of human factor on vessels of any type or size, is undeniable. Over $67 \%$ of the naval accidents analyzed above were caused by human error. Human error is due to either a malpractice or failure to fulfill the objectives at the planed performance parameters. In these accidents, human error must be considered in relation to its effect and consequences on maritime safety. Given the consequences resulting from naval accidents, it is necessary that the maritime industry to undertake engineering studies and analysis of the human factor. This interdisciplinary field have to focus on human capacity and limits, to the design and operation of complex technical systems, because the main objective of human factor engineering is to improve operating performance and increase reliability in shipping industry. In the case of shipping, achievment of this objective should lead to the reduction of operational errors, which is a characteristic of activities conducted under stress and/or fatigue, including improvement of training of crew members [10]. Some negative experiences in recent years, Costa Concordia and Deepwater Horizon, strengthen our belief that the issue of determining the human factors influence on maritime safety is still at the beginning. Therefore, research related to human factor should focus on the causal relationship between naval accidents and main causes (figure 7).

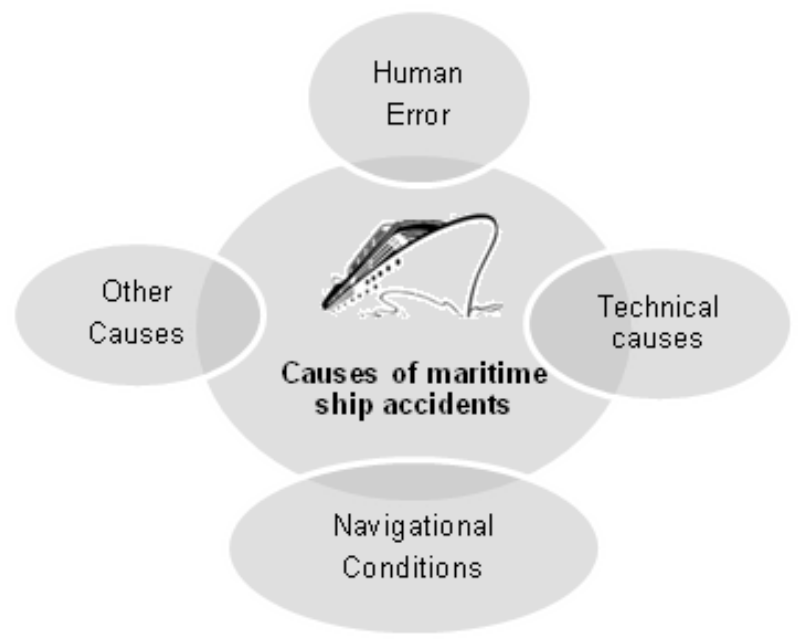

Figure 7. Overview of the main causes of naval accidents

Most times, for systems with highly complex work, such as the ship, seen as a system, investigating the human factor must be carried out for all stages in that human operator is involved. The first step is performed in the design stage, continues in operation phase, up to management level, because human factor and human error have a decisive role in the life cycle of a ship. In conclusion, risk - safety relationship can not be understood only by human operator -human reliability relationship, which depends in turn both the quality of the interaction between capabilities/competencies of human operator as well as the characteristics of the workload and conditions specific to working environment. Future research related to human factor - risk - safety relationship in the maritime industry, will focus on analyzing the interaction between operator and working procedures, man - machine interaction type, human - working conditions etc. Individual interaction within organizations, seen as multicultural groups, will be another area of interest.

\title{
BIBLIOGRAPHY
}

[1] Chauvin, C., Lardjane, S., Morel, G., Clostermann, J. P., \& Langard, B. (2013). Human and organisational factors in maritime accidents: Analysis of collisions at sea using the HFACS. Accident Analysis \& Prevention, 59, 26-37.

[2] Kristiansen, S. (2013). Maritime transportation: safety management and risk analysis.

[3] Psarros, G., Skjong, R., \& Eide, M. S. (2010). Under-reporting of maritime accidents. Accident Analysis \& Prevention, 42(2), 619-625.

[4] Corovic, B. M., \& Djurovic, P. (2013). Research of marine accidents through the prism of human factors. Promet-Traffic \& Transportation, 25(4). 
"Mircea cel Batran" Naval Academy Scientific Bulletin, Volume XIX - 2016 - Issue 1

Published by "Mircea cel Batran" Naval Academy Press, Constanta, Romania /I The journal is indexed in:

PROQUEST / DOAJ / DRJI / JOURNAL INDEX / I2OR / SCIENCE LIBRARY INDEX / Google Scholar / Crossref /

Academic Keys I ROAD Open Access / OAJI / Academic Resources / Scientific Indexing Services / SCIPIO

[5] Nicolae, F., (2015). Risk management. Concepts. Methods. Applications (in Romanian: Managementul riscului. Concepte. Metode. Aplicații), Mircea cel Batran Naval Academy Press, Constanta, ISBN 978-606642-109-6, 2015.

[6] Reason, J., (1990). Human error. Cambridge University Press, 1990.

[7] Williamson, A., Lombardi, D. A., Folkard, S., Stutts, J., Courtney, T. K., \& Connor, J. L. (2011). The link between fatigue and safety. Accident Analysis \& Prevention, 43(2), 498-515.

[8] Lützhöft, M. (2004). The technology is great when it works: Maritime Technology and Human Integration on the Ship's Bridge.

[9] Sneddon, A., Mearns, K., \& Flin, R. (2013). Stress, fatigue, situation awareness and safety in offshore drilling crews. Safety Science, 56, 80-88.

[10] Nicolae F., Popa, C., Ristea M., Beizadea H., (2013). The E-learning Particularities for Maritime Training and Education. Study Case on Training Simulator for Integrated Ship Management. The 9 $^{\text {th }}$ International Scientific Conference eLSE, e-Learning and Software for Education", National University of Defence, ISSN 2066-026X-13-148, p.250-255, Bucharest, Romania, April 25-26, 2013. 